\title{
Gambaran squamous cel/ carcinoma posterior mandibula pada radiograf panoramik
}

\author{
Gunawan ${ }^{1 *}$, Ria Noerianingsih Firman ${ }^{2}$, Farina Pramanik ${ }^{2}$, Aga Satria Nurrachman $^{3}$
}

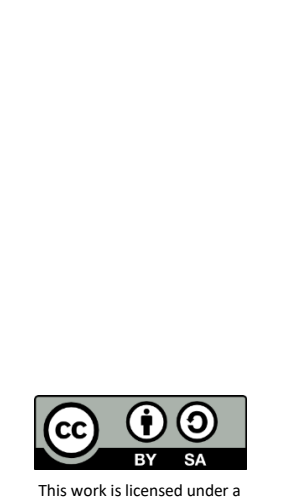

This work is licensed under a
Creative Commons Attribution 4.0
${ }^{1}$ Departemen Bedah Mulut, Perio dan Dental Radiologi, Fakultas Kedokteran Gigi, Universitas Andalas, Padang, Indonesia, 25129

2 Departemen Radiologi Kedokteran Gigi, Fakultas Kedokteran Gigi, Universitas Padjadjaran, Bandung, Indonesia 40132

${ }^{3}$ PPDGS Radiologi Kedokteran Gigi, Fakultas Kedokteran Gigi, Universitas Padjadjaran, Bandung, Indonesia 40132

*Correspondence to:

Gunawan

■gunawan_drg107@yahoo.co.id

Received on: February 2020

Revised on: April 2020

Accepted on: April 2020

\section{ABSTRACT}

Objectives: This study is aimed to report a case of mandibular left posterior squamous cell carcinoma on panoramic radiographs.

Case Report: A 61 years male patient came to the RSGM UNPAD Radiology Installation carrying a referral letter to have panoramic examination. The patient had his molars extracted one year ago, but then six months later he complained of swelling. Since one week ago he has been feeling pain and difficulty in opening his mouth, premedication of amoxicillin and paracetamol has been given. Extra oral examination showed facial asymmetry, swelling, intra-oral examination of swelling, redness accompanied by ulceration. A panoramic radiograph showed loss of left molar teeth, radiointermediate area in the left posterior region of the mandible $\pm 5 \mathrm{~cm}$, radiolucent ill-defined noncorticated, irregular in the posterior mandibular body.

Conclusion: Panoramic radiographs can be used as a supportive examination of SCC cases which show the presence of an ill-defined non-corticated radiointermediate area, irregular bone invasion.

Keywords: Squamous cell carcinoma, posterior mandibula, panoramic radiograph

Cite this article: Gunawan, Firman RN, Pramanik F, Nurrachman AS. Gambaran squamous cell carcinoma pada posterior mandibula pada radiograf panoramik. Jurnal Radiologi Dentomaksilofasial Indonesia 2020;4(1)41-4. https:// doi.org/10.32793/jrdi.v4i1.479

\section{PENDAHULUAN}

Kanker merupakan pertumbuhan abnormal sel yang tidak terkontrol, tidak ada batas yang jelas dengan jaringan yang sehat, dan memiliki beberapa sifat diantaranya anaplasia, invasi, metastase, dan pertumbuhan yang cepat. ${ }^{1,2}$ Salah satu kanker yang merupakan kanker rongga mulut dan merupakan jenis kanker rongga mulut yang paling sering terjadi, sekitar $90-95 \%$ kasus, adalah squamous cell carcinoma (SCC). SCC merupakan neoplasma maligna yang berasal dari keratinosit suprabasa epidermis. Neoplasma ini merupakan jenis neoplasma non melanoma kedua terbanyak setelah

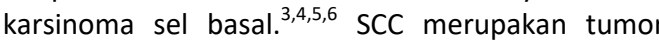
ganas yang berasal dari epitel skuamosa. SCC dapat tumbuh sebagai lesi primer ataupun metastasis dari jaringan lainnya. Etiologi SCC belum diketahu secara pasti, faktor resikonya disebabkan oleh bahan karsinogenik dan faktor predisposisi. Kanker ini lebih beresiko pada perokok, peminum alkohol, dan riwayat kanker pada garis keturunannya. ${ }^{1}$

Patogenesis dari SCC diketahui multifaktorial. Pada SCC terjadi perubahan progresif pada tingkat seluler dan genetik yang memprogram sel untuk berproliferasi secara tidak terkontrol hingga kemudian menyebabkan massa malignan. Faktorfaktor lain yang menyokong terjadinya SCC yaitu infeksi dengan virus HPV, dan jarang virus HIV. Studi mengenai ekspresi gen telah mengidentifikasi tanda -tanda transkripsi gen pada SCC rongga mulut. Beberapa juga mengaitkan dengan diet dan nutrisi yang buruk serta akumulasi dari paparan radias serta iritan karsinogenik lainnya yang berlebih. ${ }^{7}$ Karakteristik sebuah lesi patologis seringkali tidak dapat diamati secara langsung melalui pemeriksaan klinis, sehingga dokter gigi memerlukan pemeriksaan pendukung dengan cara mengamati gambaran (citra) lesi tersebut melalui radiograf. Karakterisasi tepat untuk abnormalitas pada rahang adalah hal penting untuk memastikan perawatan yang tepat bagi pasien dan mereduksi angka kesakitan (morbidity). ${ }^{7,8}$

Teknik pencitraan berperan penting dalam karakterisasi lesi pada rahang, dan seorang Spesialis Radiologi diharapkan mampu mengidentifikasi dengan baik karakteristik setiap lesi yang tampak pada radiograf. Hal ini dikarenakan gigi dan rahang merupakan jaringan keras, namun di dalam struktur gigi dan rahang terdapat jaringan lunak berupa saraf dan pembuluh darah yang sering mengalami kondisi patologis yang mengganggu kesehatan pasien. $^{8}$

Radiograf panoramik merupakan salah satu radiograf yang dapat digunakan untuk menentukan lokasi lesi, struktur lesi dan kondisi gigi pada rahang. Untuk menentukan karakteristik suatu lesi, dokter gigi harus memperhatikan beberapa 
informasi penting antara lain lokasi anatomisnya, bagaimana bentuk dan gambaran tepi lesinya, bagaimana gambaran struktur internal dari lesi tersebut, dan bagaimana efek lesi tersebut terhadap struktur anatomi di sekitar. Pertimbangan lain dalam memilih radiograf panoramik adalah karena modalitas ini merupakan modalitas yang sering dilakukan di kedokteran gigi sebagai pemeriksaan rutin, dapat melihat bentuk dan perluasan lesi dan lebih ekonomis. ${ }^{8}$

\section{LAPORAN KASUS}

Seorang pasien laki-laki umur 61 tahun datang ke Instalasi Radiologi Kedokteran Gigi RSGM FKG UNPAD membawa surat konsul untuk dilakukan foto panoramik. Anamnesa diketahui pasien pernah dilakukan pencabutan gigi molar kiri 1 tahun yang lalu, tetapi setelah enam bulan kemudian pasien mengeluhkan adanya bengkak. Sekitar satu minggu yang lalu pasien mulai merasakan sakit dan susah untuk membuka mulut. Setelah mengunjungi praktek dokter gigi pasien diminta untuk foto panoramik dan diberikan premedikasi amoxicillin dan paracetamol.

Pemeriksaan ekstra oral terlihat adanya asimetris pada wajah pasien, daerah pipi sebelah kiri terlihat bengkak, dan palpasi teraba adanya jaringan yang keras (Gambar 1A). Pada pemeriksaan intra oral terlihat adanya hiperplasia gingiva, dan adanya ulser serta lesi kemerahan (Gambar 1B). Dari pemeriksaan radiograf panoramik menunjukkan kehilangan gigi molar kiri, serta adanya area radiointermediate di regio posterior kiri mandibula $\pm 5 \times 2 \mathrm{~cm}$, radiolusen illdefined non-corticated, irreguler pada korpus mandibula posterior (Gambar 2). Pada saat itu langsung diberikan suspek diagnosis berupa lesi keganasan dengan differential diagnosis sebagai squamous cell carcinoma (SCC).
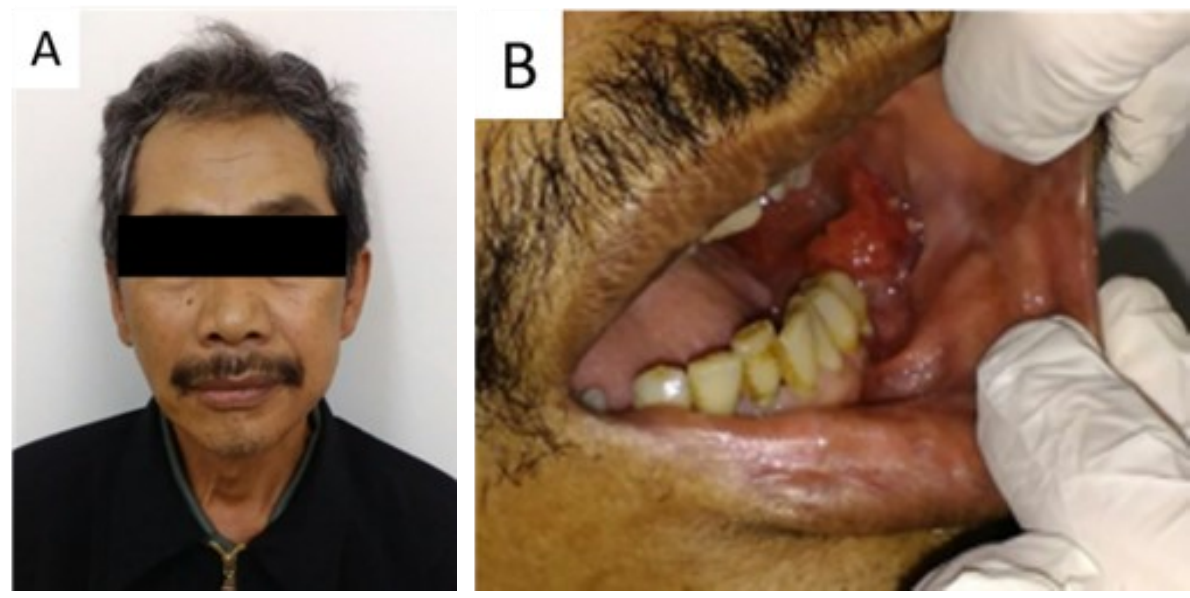

Gambar 1. Keadaan klinis pasien, (A) Tampak profil pasien menunjukkan asimetri wajah dimana tampak pembesaran pada mukosa sinistra, (B) Keadaan intraoral pasien menunjukkan adanya hyperplasia di sekitar alveolar ridge mandibula posterior sinistra

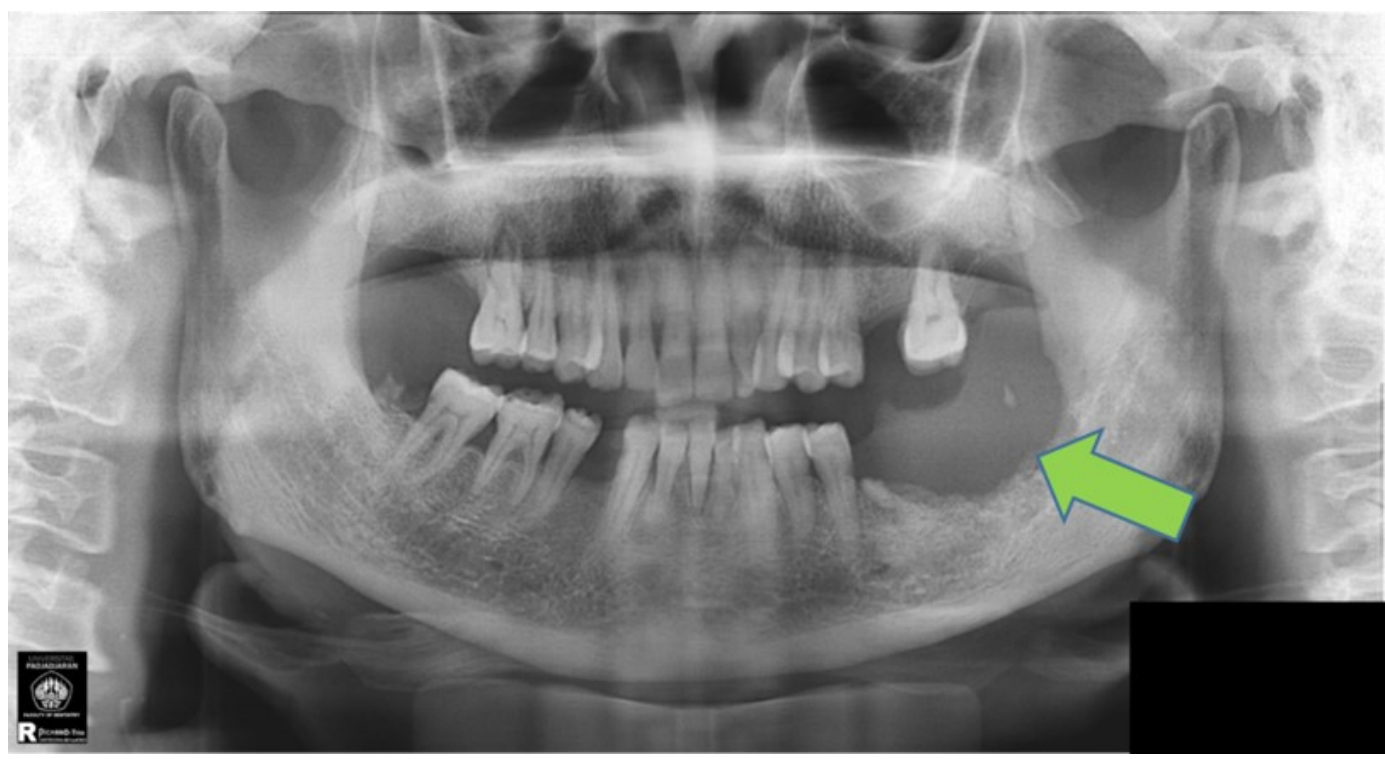

Gambar 2. Radiograf panoramik pasien menunjukkan adanya area radiointermediate dan ill-defined non corticated serta irreguler di posterior kiri mandibula (panah hijau) disertai adanya satu pulau kecil radiopak di tengah lesi yang diduga merupakan fragmen trabekula 


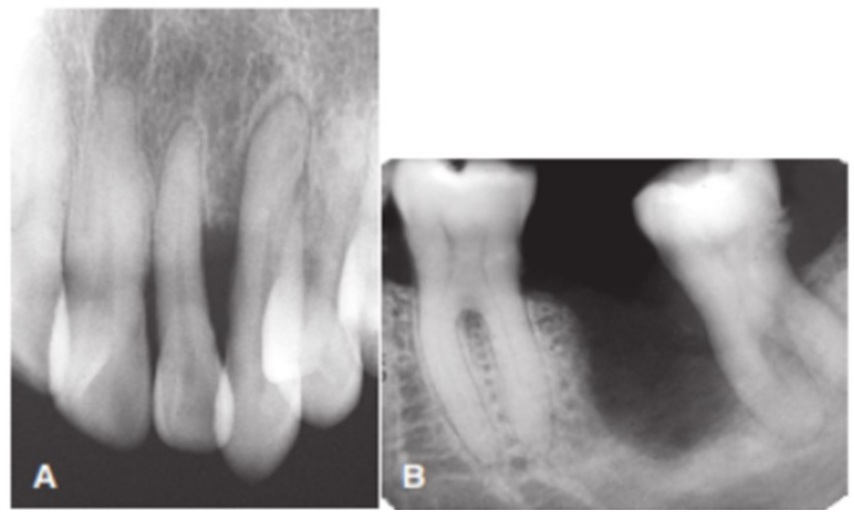

Gambar 3. Gambaran SCC yang berasal dari jaringan lunak, (A) Radiograf periapikal hanya menunjukkan gambaran destruksi tulang layaknya kerusakan pada jaringan periodontal di sekitar gigi insisif lateral yang ternyata merupakan lesi SCC, (B) Tampak pembesaran soket dan tidak terbentuknya jaringan healing di sekitar regio edentulous gigi molar 2 post ekstraksi pada kasus $\mathrm{SCC}^{3}$
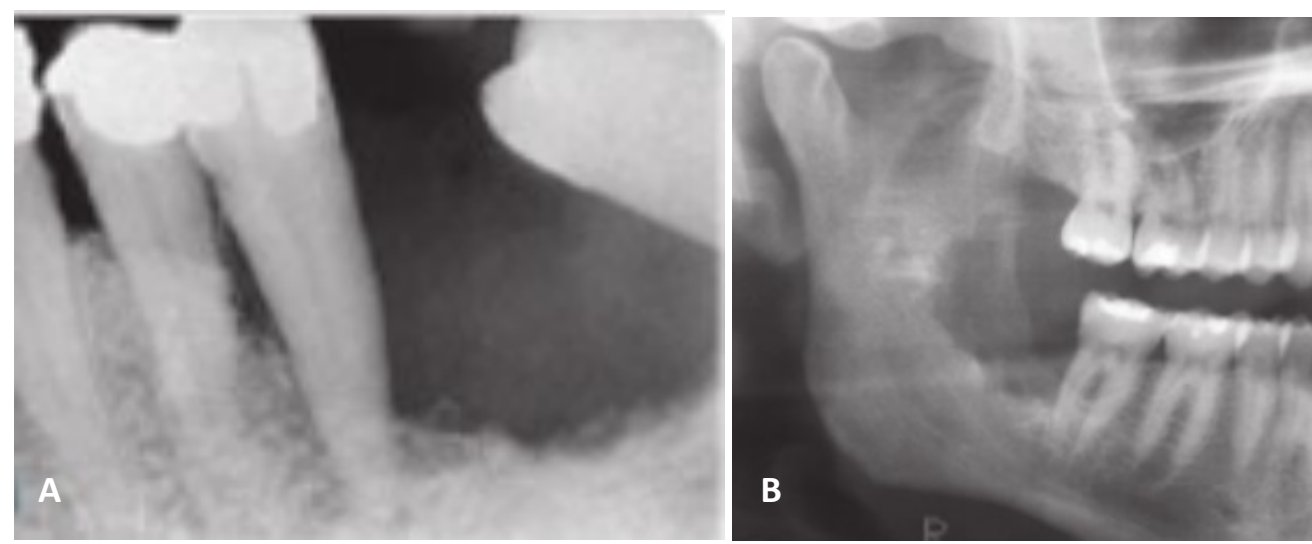

Gambar 4. Bentuk gambaran radiografi SCC yang berasal dari jaringan lunak pada kasus lain dengan pemeriksaan radiografi (A) periapikal dan (B) panoramik, tampak keduanya memberikan gambaran yang khas dengan bentuk lesi radiointermediate ill-defined disertai gambaran erosi tulang irregular seperti yang terjadi dalam kasus ini ${ }^{3}$

\section{DISKUSI}

Karsinoma rongga mulut menjadi kanker yang paling sering terjadi di seluruh dunia dimana salah satu jenis kanker rongga mulut yang paling besar mengakibatkan mortalitas adalah squamous cell carcinoma (SCC). Gambaran klinis SCC muncul sebagai lesi putih, lesi merah atau campuran, epitel tidak merata, tidak teratur. Lesi menunjukkan ulserasi, batas yang indurasi merupakan invasi sel ganas, infiltrasi sampai ke otot atau tulang yang berdekatan. Gambaran klinis lainnya berupa massa jaringan lunak, paresthesia, nyeri, bau busuk, trismus, gigi goyang, susah mengunyah dan menelan, sakit tenggorokan, disfagia, atau perdarahan. ${ }^{3}$ Pada tahap awal, SCC dapat tidak menimbulkan gejala apapun sehingga pasien dapat tidak merasa sakit apapun, hanya sepertiga dari keseluruhan kasus SCC yang didiagnosis pada tahap early. Sebagian besar pasien didiagnosis SCC ketika lesi sudah cukup besar, dimana kemudian dapat meninggal akibat komplikasi lainnya yang berkaitan dengan tumor SCC tersebut ketika lesi telah jauh meluas dan bermetastasis. ${ }^{11}$ Secara histologi, SCC menunjukkan massa yang irreguler dari sel - sel epidermis yang berproliferasi dan menginvasi ke dermis, dimana yang paling khas adalah adanya bentukan keratin pearls yang mencirikan keratinisasi abnormal. Sel-sel tumor SCC tersusun secara fokal dan konsentris disertai massa keratin. ${ }^{9,10}$

Pemeriksaan radiografi panoramik diketahui berguna pada pasien yang tidak bisa dilakukan pengambilan foto intra oral. Radiograf panoramik dapat digunakan sebagai tahap awal atau screening untuk melihat perluasan dan invasi lesi pada SCC. ${ }^{3,8}$ Diagnosis SCC secara radiograf dapat menjadi sulit karena SCC dapat berasal dari jaringan lunak, tulang, kista, atau sinus maksilaris. Setiap kasus SCC dapat memberikan gambaran yang berbeda karena gambaran radiografis SCC sendiri sangat bergantung dengan asal jaringan serta perluasan atau invasi dari lesi SCC tersebut sendiri. ${ }^{3}$ Pada kasus ini tampak lesi SCC berasal dari jaringan lunak di sekitar alveolar ridge gigi posterior mandibula sinistra dan kemudian menginvasi jaringan tulang. Hal ini tampak khas dan dapat dilihat melalui pembacaan radiograf panoramik, dimana terdapat lesi radiointermediate yang cukup besar dan destruksi tulang di puncak alveolar ridge dengan bentuk irregular. Bagaimanapun perlu diketahui jika lesi yang berasal dari jaringan lunak baru dapat memberikan gambaran kelainan yang spesifik ketika telah menginvasi jaringan tulang sekitar. Apabila lesi SCC yang berasal dari jaringan lunak hanya berukuran kecil dan tidak menginvasi 
jaringan tulang, maka dapat memberikan gambaran tidak spesifik dan dapat menunjukkan karakteristik seperti periodontitis saja (Gambar 3).

Pada umumnya lesi SCC yang berasal dari jaringan lunak melibatkan batas lateral lidah, dan invasi ke aspek lingual posterior mandibula. SCC juga dapat mengikis tulang dari segala arah, yang dimana pada umumnya menghasilkan radiolusen yang polimorf dan tidak teratur, serta dapat terjadi invasi dan adanya batas ill-defined non corticated (Gambar 4). ${ }^{3}$

Sklerosis pada struktur tulang yang mendasari (kemungkinan berasal dari penyakit radang sekunder) dapat terlihat berhubungan dengan erosi dari karsinoma permukaan. Struktur internal SCC pada lesi rahang umumnya radiolusen, struktur tulang asli bisa hilang sama sekali. Kadang-kadang, pulau-pulau kecil tulang trabekular normal sisa terlihat dalam gambaran radiolusen lesi itu sendiri, seperti yang terlihat juga pada radiograf laporan kasus ini (Gambar 2).

Penghancuran tulang yang mendalam atau karakteristik invasif yang menandakan lesi tumbuh dengan cepat dapat membantu mengidentifikasi adanya keganasan saat terjadi campuran perubahan inflamasi dan karsinoma. Osteomielitis biasanya menghasilkan beberapa reaksi periosteal, sedangkan SCC tidak. Efek lesi SCC terhadap jaringan sekitarnya juga dapat berupa pelebaran ligament periodontal space yang menimbulkan tampakan gigi floating. Lesi juga dapat menyebabkan displacement gigi, menghilangkan kanalis inferior atau foramen mentale, hingga mendestruksi atau menipiskan tulang kortikal. ${ }^{3}$

Perawatan SCC berupa operasi dan terapi radiasi. ${ }^{3}$ Pemahaman mengenai pola serta perluasan dari lesi SCC sendiri sangat berperan dalam penentuan tindakan perawatan selanjutnya, dimana dapat memberikan gambaran derajat reseksi mandibula atau surgical ablation yang harus dilakukan. SCC yang berasal dari jaringan lunak dan berukuran besar kemungkinan akan menginvasi mandibula dan menunjukkan bentukan agresif dalam perluasannya, sehingga pemilihan perawatan reseksi (rim) konservatif dihindari. ${ }^{12}$

Pemeriksaan radiologi lanjutan yang dapat menunjukkan jaringan lunak dengan lebih jelas seperti pemeriksaan CT dan MRI mungkin diperlukan jika gambaran lesi pada radiograf konvensional dinilai kurang spesifik dan kurang dapat menggambarkan karakteristik lesi secara keseluruhan. Pemeriksaan CT dan MRI dapat mendeteksi invasi lesi SCC terhadap tulang dengan lebih akurat dan seringkali dijadikan panduan utama para praktisi dalam melakukan perawatan bedah. Bagaimanapun perlu diperhatikan faktor situasional lainnya dalam pemilihan penggunaan kedua modalitas ini, seperti ada tidaknya restorasi metal pada gigi-geligi dan sebagainya. ${ }^{13}$

\section{SIMPULAN}

Gambaran squamous cell carcinoma (SCC) memiliki ciri yang khas secara umum yaitu dengan adanya gambaran area radiointermediate ill-defined non-corticated, disertai invasi tulang irreguler. Radiograf panoramik dapat dijadikan sebagai pemeriksaan penunjang kasus SCC. Bagaimanapun harus dapat dibedakan gambaran radiografi berdasarkan awal mula jaringan pertumbuhan lesi SCC tersebut dimana dapat memengaruhi jenis perawatan yang akan dilakukan. Besar lesi dan seberapa jauh invasi lesi tersebut terhadap jaringan di sekitarnya berpengaruh terhadap gambaran yang tampak dalam radiograf.

\section{DAFTAR PUSTAKA}

1. Warshawsky S, Landolph JR. Molecular carcinogenesis and the molecular biology of human cancer. Boca Raton USA : Taylor and Francis Group;2006. hlm. 6

2. Ahmad H, Satari H M, Oewen R, Supriatno. Anti-tumor agent celecoxib activity toward SP-C1 tongue cells cancer invasion (in vitro). Padjadjaran Journal of Dent. 2011; 23(1):1-5

3. White S.C, and Pharoah M.J., Oral Radiology Principles and Interpretations. 7th ed., Mosby Canada, 2014.

4. Whaites E. Essential dental radiography and radiology. 4th ed. Elsevier Spain, 2007

5. Grossman D, Leffel DJ. Squamous Cell Carcinoma. In: Wolff K, Goldsmith LA, Katz SI, Gilchrest BA, Leffell ASPJ, editors. Fitzpatrick's Dermatology in General Medicine. 7 ed. New York: McGraw-Hill; 2008. hlm. 1028-36.

6. Alam M, Ratner D. Cutaneous Squamous-Cell Carcinoma. NEJM 2001; 344: 975-83.

7. Lintong M P. Lesi prakanker dan kanker rongga mulut. Jurnal Biomedik (JBM), Volume 5, Nomor 3, Suplemen, November 2013, hlm. S43-50

8. Lestari $S$, Widyaningrum R. Karakterisasi squamous cell carcinoma pada rahang bawah dengan metode pengenalan pola pada citra radiograf panoramik digital. Jurnal Teknologi Industri. Volume 22, Nomor 1, Maret 2016. HIm 60-7

9. Neville BW, Damm DD, Allen CM, et al. Oral \& maxillofacia pathology. 3rd ed. Philadelphia : Saunders, 2009: 362-9.

10. Regezi JA, Sciubba JJ, Jordan CK. Oral pathology, clinical pathologic correlations 4th ed. China : W.B Saunders Company, 2003, 246-67.

11. Wikner J, Gröbe A, Pantel K, Riethdorf S: Squamous cell carcinoma of the oral cavity and circulating tumour cells World J Clin Oncol. 2014, 5:114-124. 10.5306/wjco.v5.i2.114

12. Brown, J.S., Lowe, D., Kalavrezos, N., D'Souza, J., Magennis, P. and Woolgar, J. (2002), Patterns of invasion and routes of tumor entry into the mandible by oral squamous cel carcinoma. Head Neck, 24: 370-383. doi:10.1002/hed.10062

13. Bernard Slieker FJ, Dankbaar JW, de Bree R, Van Cann EM Detecting Bone Invasion of the Maxilla by Oral Squamous Cell Carcinoma: Diagnostic Accuracy of Preoperative Computed Tomography Versus Magnetic Resonance Imaging [published online ahead of print, 2020 Apr 23]. J Oral Maxillofac Surg. 2020;50278-2391(20)30425-0. doi:10.1016/ j.joms.2020.04.019 